\title{
Influence of Secondary and Micronutrients on Yield and Yield Components in Groundnut (Arachis hypogaea L.)
}

\author{
G. Rajitha $^{1 *}$, M. Srinivasa Reddy ${ }^{1}$, P.V. Ramesh Babu ${ }^{1}$ and P. Uma Maheshwari ${ }^{2}$ \\ ${ }^{1}$ Department of Agronomy, ${ }^{2}$ Department of Crop Physiology, Agricultural College, \\ Mahanandi-518502, ANGRAU, Andhra Pradesh, India \\ *Corresponding author
}

\section{A B S T R A C T}

\section{Keywords \\ Groundnut, Secondary nutrients, Micronutrients, Yield attributes, Yield \\ Article Info \\ Accepted: \\ 04 August 2018 \\ Available Online: \\ 10 September 2018}

Groundnut (Arachis hypogaea L.) is a major oilseed crop of our country and edible oil economy primarily depends upon groundnut production. Intensive cropping leads to deficiency of secondary and micronutrients, which is the main constraint for low yield of groundnut. Field experiment was conducted at agricultural college farm, Mahanandi during rabi season, 2015-16 to study the response of groundnut to secondary and micronutrients. The results revealed that the highest pod yield was recorded in the treatment with application of RDF + foliar application of one per cent each of $\mathrm{CaNO}_{3}$, $\mathrm{MgNO}_{3}$ and sulphur + micronutrient mixture @ 0.2 per cent $\left(\mathrm{T}_{10}\right)\left(2654 \mathrm{~kg} \mathrm{ha}^{-1}\right)$ and it was significantly superior over control $\left(\mathrm{T}_{1}\right)\left(1118 \mathrm{~kg} \mathrm{ha}^{-1}\right)$. All other yield components were also significantly higher over recommended dose of fertilizer and control.

\section{Introduction}

Groundnut (Arachis hypogaea $\quad$ L.) the unpredictable legume is considered as heavy feeder of nutrients. The productivity of Andhra Pradesh (890 kg ha $\left.{ }^{-1}\right)$ is much lower compared to national average $\left(1750 \mathrm{~kg} \mathrm{ha}^{-1}\right)$ (INDIASTAT, 2015). There are several production constraints which could be attributed to lower productivity. Mainly the crop is grown on low fertility marginal lands with low input supply and rainfed conditions. The productivity enhancement target is still elusive. With limited scope of bringing additional area under oilseeds, bulk of the future increase in production has to come through crop nutrition. Therefore, it is most essential to pay a great attention to the nutrition of the groundnut to enhance its productivity. Intensification of agriculture, usage of straight fertilizers, rising crop requirements due to increasing productivity levels have heightened the secondary and micronutrients demand in soil fertility management and are increasingly becoming major constraints to achieve augmented agricultural production.

Among the oilseed crops, groundnut responds well to secondary and micronutrient 
fertilization. Depletion of secondary and micronutrients necessitates periodic or yearly supply of these nutrients. Further, we should replenish secondary and micronutrients appropriately because their dearth can hinder groundnut response to major nutrients, irrigation and several other agronomic practices. The nutrient requirement of groundnut is high especially at pegging and pod development stages. The requirement at these stages cannot be fulfilled merely by soil application alone and need to be supplemented through foliar application. Foliar spray enables plants to absorb the applied nutrients from the solution through their leaf surface and thus, may result in the economic use of fertilizer. Foliar absorption is most effective and the rate of absorption is generally higher in younger points of branches or stem tips (Helmy and Shaban, 2008). Hence, the present study was conducted to see the effect of secondary and micronutrients on growth and yield of groundnut.

\section{Materials and Methods}

Field experiment was conducted with groundnut variety K6, under irrigated conditions during rabi, 2015-16 on sandy loam soils of Agricultural College Farm, Mahanandi, Andhra Pradesh. The farm geographically situated at $15^{\circ} .51^{\prime} \mathrm{N}$ latitude and $78^{\circ} .61^{\prime} \mathrm{E}$ longitude with an altitude of 233.48 meters above the mean sea level in Scarce rainfall zone of Andhra Pradesh and according to Troll's classification, it falls under Semi-Arid Tropics (SAT). The soil of the experimental field was neutral in $\mathrm{pH}$ (7.38), medium in organic carbon $(0.59 \%), \mathrm{N}$ (319 $\left.\mathrm{kg} \mathrm{ha}^{-1}\right), \mathrm{P}_{2} \mathrm{O}_{5}\left(40 \mathrm{~kg} \mathrm{ha}^{-1}\right)$ and high in $\mathrm{K}_{2} \mathrm{O}$ (369 $\mathrm{kg} \mathrm{ha}^{-1}$ ). Exchangeable calcium, magnesium $\left(2.85\right.$ and $1.12 \mathrm{C} \mathrm{mol} .\left(\mathrm{P}^{+}\right) \mathrm{kg}^{-1}$ ) and available sulphur (30 $\mathrm{kg} \mathrm{ha}^{-1}$ ) were sufficient in availability. Whereas, micronutrients availability (Fe, $\mathrm{Mn}, \mathrm{Zn}, \mathrm{Cu}, \mathrm{B}$ and Mo) was more than their critical limits.
Weather during the crop growth period was normal without any marked deviation from mean of the experimental site. The experiment was laid out in a randomized block design having ten treatments and replicated thrice. The treatments consisting of $\mathrm{T}_{1}$ : Control, $\mathrm{T}_{2}$ : RDF: 20-40-50 kg N-P $\mathrm{O}_{5}-\mathrm{K}_{2} \mathrm{O} \mathrm{ha}^{-1}, \mathrm{~T}_{3}$ : RDF + foliar application of one per cent $\mathrm{CaNO}_{3}, \mathrm{~T}_{4}$ : $\mathrm{RDF}+$ foliar application of one per cent $\mathrm{MgNO}_{3}, \mathrm{~T}_{5} \mathrm{RDF}+$ foliar application of one per cent sulphur, $\mathrm{T}_{6}$ : $\mathrm{RDF}+$ foliar application of one per cent each of $\mathrm{CaNO}_{3}, \mathrm{MgNO}_{3}$ and sulphur, $\mathrm{T}_{7:} \mathrm{RDF}+$ foliar application of $\mathrm{ZnSO}_{4} @ 0.2$ per cent, $\mathrm{T}_{8} \mathrm{RDF}+$ foliar application of one per cent each of $\mathrm{CaNO}_{3}$, $\mathrm{MgNO}_{3}$ and sulphur + foliar application of $\mathrm{ZnSO}_{4} @ 0.2$ per cent, $\mathrm{T}_{9:} \mathrm{RDF}+$ foliar application of micronutrient mixture @ 0.2 per cent and $\mathrm{T}_{10}$ : $\mathrm{RDF}+$ foliar application of one per cent each of $\mathrm{CaNO}_{3}, \mathrm{MgNO}_{3}$ and sulphur + micronutrient mixture @ 0.2 per cent. Urea, single super phosphate and muriate of potash were used for the supply of NPK and was applied as basal dose at the time of sowing. Whereas secondary nutrients and zinc was supplied through $\mathrm{CaNO}_{3}, \mathrm{MgNO}_{3}$, wettable sulphur and $\mathrm{ZnSO}_{4}$ respectively. Micronutrient mixture consists of Boron (B) 1.5\%, Copper (Cu) $0.5 \%$, Iron (Fe) 3.4\%, Manganese (Mn) $3.2 \%$, Molybdenum (Mo) $0.05 \%$ and Zinc (Zn) $4.2 \%$. Foliar spray of secondary and micronutrients was done at 22 DAS. Seed treatment was done with Trichoderma viride @ 10 grams per kilo gram seed as prophylactic measure against seed born diseases.

\section{Results and Discussion}

\section{Effect of secondary and micronutrients on yield attributes}

Different combinations of secondary and micronutrients had significant effect on yield attributes of groundnut (Table 1). Yield attributes viz., number of pods per plant, 100- 
kernel weight and shelling percentage were found to be significantly highest with RDF + foliar application of one per cent each of $\mathrm{CaNO}_{3}, \mathrm{MgNO}_{3}$ and sulphur + micronutrient mixture @ 0.2 per cent $\left(\mathrm{T}_{10}\right)$ which was at par with RDF + foliar application of one per cent each of $\mathrm{CaNO}_{3}, \mathrm{MgNO}_{3}$ and sulphur + foliar application of $\mathrm{ZnSO}_{4} @ 0.2$ per cent $\left(\mathrm{T}_{8}\right)$. Higher dry matter production coupled with effective translocation of assimilates to the sink would have resulted in elevated stature of all the yield attributes (Heba Mohamed Noman et al., 2015).

Among the secondary nutrients sources along with RDF treatments, RDF + foliar application of one per cent sulphur $\left(\mathrm{T}_{5}\right)$ recorded higher number of pods per plant, 100-kernel weight and shelling percentage than $\mathrm{RDF}+$ foliar application of one per cent $\mathrm{CaNO}_{3}\left(\mathrm{~T}_{3}\right)$, but on par with $\mathrm{RDF}+$ foliar application of one per cent $\mathrm{MgNO}_{3}\left(\mathrm{~T}_{4}\right)$ in case of 100-kernel weight and shelling percentage.Sulphur plays a vital role in heavier seed production and higher oil content. Umadevi et al., (1999) concluded that groundnut can produce qualitative and bigger kernels if the elements like calcium in company with sulphur were used.

Between RDF along with micronutrient sources treatments, RDF + foliar application of micronutrient mixture @ 0.2 per cent $\left(\mathrm{T}_{9}\right)$ and $\mathrm{RDF}+$ foliar application of $\mathrm{ZnSO}_{4} @ 0.2$ per cent $\left(\mathrm{T}_{7}\right)$ were on par with each other with respect to yield attributes. An adequate supply of zinc enhanced the metabolic activity which results in increased yield characters (Mohapatra and Dixit, 2010).

Effect of secondary and micronutrients on pod and haulm yield

The highest pod and haulm yield obtained with $\mathrm{RDF}+$ foliar application of one per cent each of $\mathrm{CaNO}_{3}, \mathrm{MgNO}_{3}$ and sulphur + micronutrient mixture @ 0.2 per cent $\left(\mathrm{T}_{10}\right)$ treatment might be due to supply of secondary and micronutrients along with NPK enhanced the dry matter accumulation which subsequently improved the number of filled pods per plant.

The positive response of secondary and micronutrients with recommended NPK can be attributed to the availability of sufficient amount of plant nutrients throughout the growth period, resulting in better lateral root growth, catalyzing the metabolism of carbohydrates, increase in enzyme activity, other biological oxidation reactions and yield advantage (Nayak et al., 2009).

With regard to secondary nutrient sources along with $\mathrm{RDF}$ treatments, $\mathrm{RDF}+$ foliar application of one per cent sulphur $\left(\mathrm{T}_{5}\right)$ recorded higher pod yield than $\mathrm{RDF}+$ foliar application of one per cent $\mathrm{CaNO}_{3}\left(\mathrm{~T}_{3}\right)$ which was recorded the highest haulm yield. Highest pod yield might be due to multiple role of sulphur in metabolism and efficient partitioning and translocation of metabolites. The highest haulm yield due to calcium foliar spray might be due to effective participation of calcium in structural and developmental processes of plant growth (Kamara et al., 2011).

With regard to micronutrients foliar spray along with RDF and without secondary nutrients combination treatments, RDF + foliar application of micronutrient mixture @ 0.2 per cent $\left(\mathrm{T}_{9}\right)$ and $\mathrm{RDF}+$ foliar application of $\mathrm{ZnSO}_{4} @ 0.2$ per cent $\left(\mathrm{T}_{7}\right)$ were on par with each other.

This clearly shows the micronutrients especially zinc involvement in plant metabolism, auxin production which ultimately improves the vegetative growth of the plant and nutrient assimilation resulted in increased pod and haulm yield (Fakeerappa Arabhanvi et al., 2015). 
Table.1 Effect of secondary and micronutrients on yield attributes and yield of groundnut

\begin{tabular}{|c|c|c|c|c|c|}
\hline \multirow[t]{2}{*}{ Treatments } & \multicolumn{3}{|c|}{ Yield attributes } & \multicolumn{2}{|c|}{ Yield $\left(\mathrm{kg} \mathrm{ha}^{-1}\right)$} \\
\hline & $\begin{array}{c}\text { Number } \\
\text { of pods } \\
\text { per plant }\end{array}$ & $\begin{array}{c}100- \\
\text { kernel } \\
\text { weight } \\
\text { (g) }\end{array}$ & $\begin{array}{c}\text { Shelling } \\
\text { percentage } \\
(\%)\end{array}$ & Pod yield & Haulm yield \\
\hline $\mathrm{T}_{1}$ : Control & 17.00 & 30.25 & 54.27 & 1118 & 2070 \\
\hline $\mathrm{T}_{2}: 20-40-50 \mathrm{~kg} \mathrm{~N}-\mathrm{P}_{2} \mathrm{O}_{5}-\mathrm{K}_{2} \mathrm{O} \mathrm{ha}^{-1}$ & 20.33 & 33.79 & 59.39 & 1500 & 2641 \\
\hline $\mathrm{T}_{3}: \mathrm{T}_{2}+$ foliar application of $1 \% \mathrm{CaNO}_{3}$ & 21.00 & 36.65 & 64.10 & 1790 & 3095 \\
\hline $\mathrm{T}_{4}: \mathrm{T}_{2}+$ foliar application of $1 \% \mathrm{MgNO}_{3}$ & 20.67 & 37.51 & 66.70 & 1811 & 2713 \\
\hline $\mathrm{T}_{5}: \mathrm{T}_{2}+$ foliar application of $1 \%$ Sulphur & 23.00 & 39.07 & 68.56 & 1932 & 3020 \\
\hline $\mathrm{T}_{6}: \mathrm{T}_{2}+$ foliar application of $1 \%$ each of $\mathrm{CaNO}_{3}, \mathrm{MgNO}_{3}$ and Sulphur & 24.00 & 41.55 & 69.25 & 2383 & 3307 \\
\hline $\mathrm{T}_{7}: \mathrm{T}_{2}+$ foliar application of $\mathrm{ZnSO}_{4} @ 0.2 \%$ & 21.00 & 37.55 & 66.02 & 1951 & 3039 \\
\hline $\mathrm{T}_{8}: \mathrm{T}_{6}+$ foliar application of $\mathrm{ZnSO}_{4} @ 0.2 \%$ & 25.67 & 42.95 & 69.79 & 2538 & 3484 \\
\hline $\mathrm{T}_{9}: \mathrm{T}_{2}+$ foliar application of micronutrient mixture @ $0.2 \%$ & 21.33 & 39.20 & 66.62 & 1976 & 3101 \\
\hline $\mathrm{T}_{10}: \mathrm{T}_{6}+$ foliar application of micronutrient mixture @ $0.2 \%$ & 27.33 & 44.85 & 70.27 & 2654 & 3603 \\
\hline SEm \pm & 0.64 & 0.74 & 1.17 & 37 & 58 \\
\hline $\mathrm{CD}(\mathrm{P}=0.05)$ & 1.91 & 2.21 & 3.51 & 110 & 175 \\
\hline
\end{tabular}


Table.2 Effect of secondary and micronutrients on Gross returns $\left(₹\right.$ ha $\left.{ }^{-1}\right)$, Net returns $\left(₹\right.$ ha $\left.{ }^{-1}\right)$ and B: C ratio of groundnut

\begin{tabular}{|c|c|c|c|c|}
\hline Treatments & $\begin{array}{l}\text { Total cost of } \\
\text { cultivation }\left(₹ \mathrm{ha}^{-1}\right)\end{array}$ & $\begin{array}{l}\text { Gross returns } \\
\qquad\left(₹ \mathrm{ha}^{-1}\right)\end{array}$ & $\begin{array}{l}\text { Net returns } \\
\qquad\left(₹ \mathrm{ha}^{-1}\right)\end{array}$ & $\begin{array}{l}\text { B:C } \\
\text { Ratio }\end{array}$ \\
\hline $\mathrm{T}_{1}$ : Control & 36410 & 44713 & 8303 & 1.23 \\
\hline $\mathrm{T}_{2}: 20-40-50 \mathrm{~kg} \mathrm{~N}-\mathrm{P}_{2} \mathrm{O}_{5}-\mathrm{K}_{2} \mathrm{Oha}^{-1}$ & 41388 & 60011 & 18623 & 1.45 \\
\hline $\mathrm{T}_{3}: \mathrm{T}_{2}+$ foliar application of $1 \% \mathrm{CaNO}_{3}$ & 42038 & 63584 & 21546 & 1.51 \\
\hline $\mathrm{T}_{4}: \mathrm{T}_{2}+$ foliar application of $1 \% \mathrm{MgNO}_{3}$ & 41988 & 72458 & 30470 & 1.73 \\
\hline $\mathrm{T}_{5}: \mathrm{T}_{2}+$ foliar application of $1 \%$ Sulphur & 42488 & 77307 & 34819 & 1.82 \\
\hline $\mathrm{T}_{6}: \mathrm{T}_{2}+$ foliar application of $1 \%$ each of $\mathrm{CaNO}_{3}, \mathrm{MgNO}_{3}$ and Sulphur & 43738 & 95310 & 51572 & 2.18 \\
\hline $\mathrm{T}_{7}: \mathrm{T}_{2}+$ foliar application of $\mathrm{ZnSO}_{4} @ 0.2 \%$ & 42188 & 78050 & 35862 & 1.85 \\
\hline $\mathrm{T}_{8}: \mathrm{T}_{6}+$ foliar application of $\mathrm{ZnSO}_{4} @ 0.2 \%$ & 44538 & 101534 & 56996 & 2.28 \\
\hline$T_{9}: T_{2}+$ foliar application of micronutrient mixture @ 0.2\% & 42388 & 79029 & 36641 & 1.86 \\
\hline $\mathrm{T}_{10}: \mathrm{T}_{6}+$ foliar application of micronutrient mixture @ $0.2 \%$ & 44738 & 110145 & 65407 & 2.46 \\
\hline SEm \pm & --- & 1836 & 1836 & 0.05 \\
\hline $\mathrm{CD}(\mathrm{P}=\mathbf{0 . 0 5})$ & --- & 5507 & 5507 & 0.15 \\
\hline
\end{tabular}


Fig.1 Effect of secondary and micronutrients on Gross returns $\left(₹ \mathrm{ha}^{-1}\right)$, Net returns $\left(₹ \mathrm{ha}^{-1}\right)$ and B: C ratio of groundnut

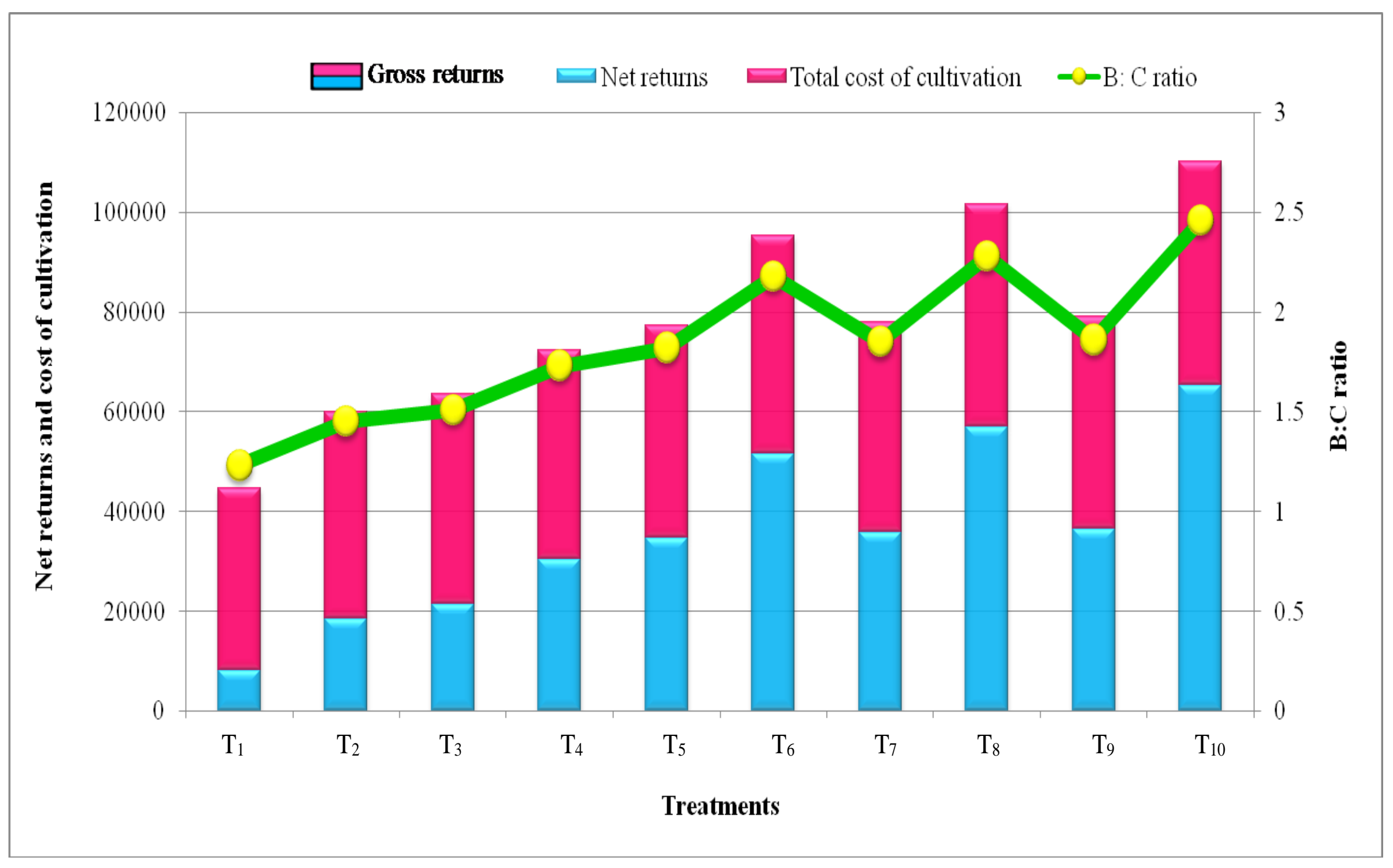




\section{Economics}

Economics of raising a particular crop plays a vital role in making recommendations for adoption of a technology to the farmers.

The data pertaining to gross returns, net returns and B: C ratio as influenced by foliar spray of secondary and micronutrients are presented in Table 2 and depicted in Figure 1.

Among all the treatments, gross, net returns and $B$ : C ratio were found highest ( $₹ 110,145$ $\mathrm{ha}^{-1}, ₹ 65,407 \mathrm{ha}^{-1}$ and 2.46 respectively) with $\mathrm{RDF}+$ foliar application of one per cent each of $\mathrm{CaNO}_{3}, \mathrm{MgNO}_{3}$ and sulphur + micronutrient mixture @ 0.2 per cent $\left(\mathrm{T}_{10}\right)$ followed by $\mathrm{RDF}+$ foliar application of one per cent each of $\mathrm{CaNO}_{3}, \mathrm{MgNO}_{3}$ and sulphur $+\mathrm{ZnSO}_{4} @ 0.2$ per cent $\left(\mathrm{T}_{8}\right)$ and $\mathrm{RDF}+$ foliar application of one per cent each of $\mathrm{CaNO}_{3}$, $\mathrm{MgNO}_{3}$ and sulphur $\left(\mathrm{T}_{6}\right)$.

Higher gross, net returns and $\mathrm{B}$ : $\mathrm{C}$ ratio was due to more pod yield than other treatments.

In conclusion, Groundnut responds to fertilizer application. Substantial increase in groundnut production can be achieved through effective nutrient management.

For groundnut, which is a legume, main focus should be on nutrients.

Combined foliar application of secondary and micronutrients along with recommended dose of fertilizer could be evolved as best combination for higher productivity and profitability of groundnut.

\section{Acknowledgements}

The corresponding author is thankful to Acharya N. G. Ranga Agricultural University (ANGRAU) for financial support.

\section{References}

Fakeerappa Arabhanvi, Amit Pujar and Hulihalli, U. K. 2015. Micronutrients and productivity of Agricultural Reviews. 36(4): 345-348.oilseed crops A review.

Heba Mohamed Noman, Rana, D.S and Rana, K.S. 2015. Influence of sulphur and zinc levels and zinc solubilizer on productivity, economics and nutrient uptake in groundnut (Arachis hypogaea L.). Indian Journal of Agronomy. 60(2): 301-306.

Helmy, A. M and Shaban, Kh. A. 2008. Response of peanuts to $\mathrm{K}$ fertilization and foliar spraying with zinc and boron under sandy soil conditions. Zagazig Journal of Agricultural Research. 35(2): 343-362.

Indian Statistics. 2015. http://www. indiastat.com.

Kamara, E.G., Olympio, N.S and Asibuo, J.Y. 2011. Effect of calcium and phosphorus fertilizer on the growth and yield of groundnut (Arachis hypogaea L.). International Research Journal of Agricultural Science and Soil Science. 1(8): 326-331.

Mohapatra, A.K.B and Dixit, L. 2010. Integrated nutrient management in rainy season groundnut (Arachis hypogaea L.). Indian Journal of Agronomy. 55(2): 123-127.

Nayak, S. C., Sarangi, D., Mishra, G. C and Rout, D.P. 2009. Response of groundnut to secondary and micronutrients. ejournal.icrisat.org. 7: $1-2$.

Uma Devi, M., Munaswamy, V., Santaiah, V and Prasad Rao, A. 1999. Uptake of major and secondary nutrients by groundnut as affected by sulphur levels under farmer's field conditions. Legume Research. 22(1): 31-35. 


\section{How to cite this article:}

Rajitha, G., M. Srinivasa Reddy, P.V. Ramesh Babu and Uma Maheshwari, P. 2018. Influence of Secondary and Micronutrients on Yield and Yield Components in Groundnut (Arachis hypogaea L.). Int.J.Curr.Microbiol.App.Sci. 7(09): 309-316. doi: https://doi.org/10.20546/ijcmas.2018.709.038 